\title{
Review
}

\section{COVID-19 and Parkinson's Disease: What Do We Know So Far?}

\author{
Carlo Alberto Artusi ${ }^{\mathrm{a}, \mathrm{b}, 1}$, Alberto Romagnolo ${ }^{\mathrm{a}, \mathrm{b}, 1}$, Claudia Ledda $^{\mathrm{a}, \mathrm{b}}$, Maurizio Zibetti $^{\mathrm{a}, \mathrm{b}}$, \\ Mario Giorgio Rizzone ${ }^{\mathrm{a}, \mathrm{b}}$, Elisa Montanaro ${ }^{\mathrm{b}}$, Marco Bozzali ${ }^{\mathrm{a}, \mathrm{b}, \mathrm{c}}$ and Leonardo Lopiano ${ }^{\mathrm{a}, \mathrm{b}, *}$ \\ a Department of Neuroscience "Rita Levi Montalcini", University of Torino, Torino, Italy \\ ${ }^{\mathrm{b}}$ Neurology 2 Unit, A.O.U. Città della Salute e della Scienza di Torino, Torino, Italy \\ ${ }^{\mathrm{c}}$ Department of Neuroscience, Brighton and Sussex Medical School, Brighton, East Sussex, United Kingdom
}

Accepted 29 January 2021

Pre-press 18 March 2021

\begin{abstract}
.
Background: Many studies on Parkinson's disease (PD) patients affected by Coronavirus-disease-2019 (COVID-19) were recently published. However, the small sample size of infected patients enrolled in most studies did not allow to draw robust conclusions on the COVID-19 impact in PD.

Objective: We aimed to assess whether the prevalence and outcome of COVID-19 in PD patients are different from those observed in the general population.

Methods: We conducted a systematic review of studies reporting data on PD patients with a diagnosis of COVID-19 (PDCOVID+). We extracted prevalence, clinical-demographic data, outcome, and mortality. We also analyzed risk or protective factors based on comparisons between PD-COVID+ and control populations with PD without COVID-19 or without PD with COVID-19.

Results: We included 16 studies reporting on a total of 11,325 PD patients, 1,061 with a confirmed diagnosis of COVID-19. The median infection prevalence ranged from $0.6 \%$ to $8.5 \%$. PD-COVID+ patients had a median age of 74 and a disease duration of 9.4 years. Pooling all PD-COVID+ patients from included studies, $28.6 \%$ required hospitalization, $37.1 \%$ required levodopa dose increasing, and $18.9 \%$ died. The case fatality was higher in PD-COVID+ patients than the general population, with longer PD duration as a possible risk factor for worse outcome. Amantadine and vitamin D were proposed as potential protective factors.

Conclusion: Available studies indicate a higher case fatality in PD patients affected by COVID-19 than the general population. Conversely, current literature does not definitively clarify whether PD patients are more susceptible to get infected. The potential protective role of vitamin $\mathrm{D}$ and amantadine is intriguing but deserves further investigation.
\end{abstract}

Keywords: Parkinson's disease, COVID-19, infection, outcome, mortality, amantadine

\footnotetext{
${ }^{1}$ These authors contributed equally to this work.

*Correspondence to: Leonardo Lopiano, MD, PhD, Department of Neuroscience "Rita Levi Montalcini", University of Torino, Via Cherasco 15, 10126, Torino, Italy; Neurology 2 Unit, A.O.U. Città della Salute e della Scienza di Torino, Corso Bramante 88, 10124, Torino, Italy. Tel.: +0039 0116709366 ; E-mail: leonardo.lopiano@unito.it.
}

\section{INTRODUCTION}

In late 2019, the severe acute respiratory syndrome coronavirus 2 (SARS-CoV-2) began circulating across the world and caused a human disease named coronavirus disease 2019 (COVID-19) [1]. The most common symptoms of COVID-19 include fever, cough, and dyspnea, with the development of pneumonia or sepsis in a proportion of critical cases 
[2]. While the presence of neurological manifestations in patients with COVID-19 has been broadly reported [3], the interaction between COVID-19 and pre-existing chronic neurological diseases remains to be clarified. In particular, the impact of COVID19 on people with Parkinson's disease (PD) is not well defined [4]. Pre-existing medical issues and older age have been associated with more severe manifestations of COVID-19 in the general population [5, 6], and neurological comorbidities seem to have an independent negative impact on SARS-CoV-2 infection's severity and outcome [7, 8]. Moreover, the potential neurotropism of SARSCoV-2 [9, 10], the commonly observed presence of hyposmia in infected patients [11], the potential expression of angiotensin-converting enzyme 2 (ACE2) in dopaminergic neurons and astrocytes mediated by inflammation [4, 12], and previous finding of antibodies against coronavirus in the cerebrospinal fluid of PD patients [13], prompted questions about the relationship between COVID19 and PD. Nonetheless, whether PD patients have a higher risk for developing COVID-19 or result in a significantly worse clinical outcome has not been elucidated yet.

We performed here a systematic review of the existing literature with the following aims: 1 ) to summarize the prevalence, course, and clinical outcome of patients with PD who developed COVID-19;2) to identify the main clinical-demographic characteristics of infected patients; and 3) to outline potential predictors of a worse clinical outcome alongside protective conditions.

\section{METHODS}

We conducted a systematic review following the Preferred Reporting Items for Systematic Reviews and Meta-analyses (PRISMA) [14]. PubMed was searched for case reports, case series, observational, cross-sectional, and case-control studies on January 10,2021 , reporting data on PD patients with a confirmed diagnosis of COVID-19 using the following search string: "Parkinson's disease [MeSH] AND COVID-19".

Abstracts and full-text articles were carefully reviewed for eligibility criteria and to identify and exclude duplications of studies. Only studies referring to human subjects and published in English were considered. No restrictions were applied to sex, age, disease duration, disease severity, or follow-up. Each selected article's reference list was further reviewed to include any additional studies that were not captured by the original search strategy.

We used a standardized data collection form to extract, from each selected study, the following information where available: study design, criteria of patients' selection, country or region of the sample, number of enrolled patients, number of PD patients with a confirmed diagnosis of COVID-19 by nasopharyngeal swab (PD-COVID+), sex, age, and disease duration of PD-COVID+, number of PDCOVID+ needing hospitalization, number of deaths among PD-COVID+, number of PD-COVID+ for whom dopaminergic therapy was augmented during COVID-19, number of PD-COVID+ living in a nursing home. Moreover, when reported, data from the comparison between PD-COVID+ and control populations (with PD without COVID-19 or without PD with COVID-19) and specific inference or authors' notes about the presence of potential risk or protective factors were searched and registered.

Extracted data were analyzed and summarized by descriptive statistics, using prevalence, median, and range, or mean and standard deviation (SD). When possible, we pooled together all patients from included studies to obtain a global prevalence for specific events (e.g., mortality, hospitalization, etc.).

\section{RESULTS}

We included 16 studies (six case-control studies, three cross-sectional studies, five case series, and two case reports) [12, 15-29] (Fig. 1, Table 1) reporting on a total of 11,325 PD patients, 1,061 with a confirmed diagnosis of COVID-19 (or, for two studies [15, 16], with either a real-time PCR assay or symptoms compatible with COVID-19 and ascertained contact with a PCR-confirmed case).

\section{Clinical and demographic characteristics of infected $P D$ patients}

PD-COVID+ were males in $58.4 \%$ of cases, with a median age of 74 years (range 58-80.5) and a median disease duration of 9.4 years (range 6.3-22).

From ten studies reporting the information [12, $15,17,19,21,22,26-29], 11 \%$ of PD-COVID+ $(n=19 / 173)$ were treated with device-aided therapies: ten of them with levodopa/carbidopa intestinal gel infusion, eight with deep brain stimulation (two of them targeting the subthalamic nucleus, the remaining ones with an unknown target), and one with 

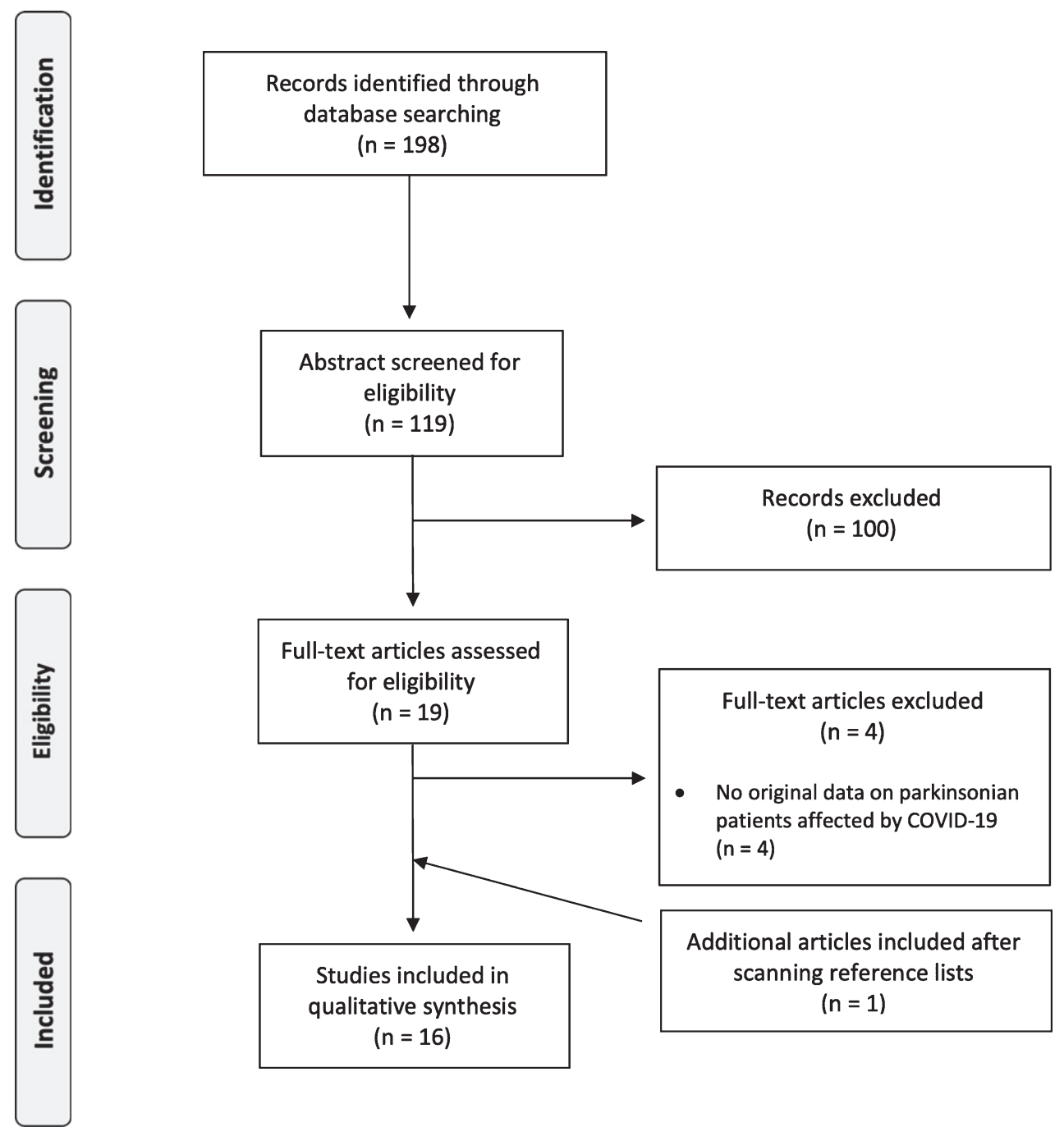

Fig. 1. Flow-chart of the systematic review.

subthalamic deep brain stimulation plus apomorphine pump.

From six studies reporting such an information [12, $21,24,26,28,29], 46.8 \%$ of PD-COVID+ $(n=22 / 47)$ were living in a nursing home. It should be noted that this data was inflated by the extremely high percentage of PD-COVID+ (63.6\%) reported in a single case series on patients living in Connecticut, US [24]. Excluding this study, the prevalence of PD-COVID+ from nursing homes is $32 \%(n=8 / 25)$.

\section{Prevalence, course, and outcome of COVID-19 in patients with $P D$}

The prevalence of COVID-19 among PD patients was available in seven studies [15, 16, 20-22, 25, 28].
It varied according to the geographical location, with a prevalence of $2.6 \%$ in Spain, $0.9 \%$ in the US, and variable values in different regions of Italy, ranging from $7.1-8.5 \%$ in Lombardy, $0.9 \%$ in Tuscany, and $0.6 \%$ in Piedmont and in the Bologna district.

The hospitalization rate was retrieved in thirteen studies, with a prevalence of $28.6 \%(n=101 / 353)$ [12, 15-22, 24-26, 29]. From six studies reporting therapy information $[12,15,19,21,26,29], 37.1 \%$ of PD-COVID+ $(n=13 / 35)$ required an increase of the levodopa dose during the duration of infection due to worsening of PD-related symptoms.

Pooling together data from all included studies, we found an overall mortality rate of $18.9 \%$ $(n=201 / 1061)$. One study specifically aimed at analyzing the case fatality of PD-COVID+ vs. people 
Table 1

Included studies

\begin{tabular}{|c|c|c|c|c|c|c|c|c|c|c|c|c|c|c|}
\hline & Geographical area & Study design & Selection & PD-COVID+ & Sex (males) & Age & $\begin{array}{l}\text { Disease } \\
\quad \text { duration }\end{array}$ & Hospitalization & Comorbidities & Deaths & $\begin{array}{r}\text { Nursing } \\
\text { home }\end{array}$ & $\begin{array}{l}\text { Levodopa } \\
\text { increase }\end{array}$ & $\begin{array}{c}\text { Device- } \\
\text { aided } \\
\text { therapy } \\
\end{array}$ & $\begin{array}{l}\text { Comparisons adjusted } \\
\text { for age or PD } \\
\text { duration } \\
\end{array}$ \\
\hline $\begin{array}{l}\text { Cilia et al., } \\
2020[15]^{*}\end{array}$ & Italy (Lombardy) & $\begin{array}{l}\text { Case control } \\
\text { (phone/web } \\
\text { survey) }\end{array}$ & $\begin{array}{l}\text { Random selection of } 141 \\
\text { PD for interview }\end{array}$ & 12 & $5(41.7 \%)$ & 65.5 & 6.3 & 1 & 9 & $0(0 \%)$ & NR & 4 & $1 \mathrm{LCIG}$ & $\begin{array}{l}\text { PD without COVID-19 } \\
\text { matched for age and } \\
\text { PD duration }\end{array}$ \\
\hline $\begin{array}{l}\text { Fasano et al., } \\
\quad 2020[16]^{*}\end{array}$ & Italy (Lombardy) & $\begin{array}{l}\text { Case control } \\
\quad \text { (phone/web } \\
\text { survey) }\end{array}$ & $\begin{array}{l}\text { 1,486 PD patients living } \\
\text { in Lombardy and } \\
\text { with at least one visit } \\
\text { at the tertiary center } \\
\text { Parkinson institute of } \\
\text { Milan }\end{array}$ & $\begin{array}{l}32 \text { PD COVID+ } \\
\text { confirmed and } \\
73 \text { PD COVID+ } \\
\text { probable }\end{array}$ & $55(52.4 \%)$ & 70.5 & 9.9 & 18 & 78 & $6(5.7 \%)$ & NR & NR & NR & $\begin{array}{l}\text { Family members with } \\
\text { COVID-19 and } \\
\text { without PD compared } \\
\text { adjusting for age }\end{array}$ \\
\hline $\begin{array}{l}\text { Del Prete et } \\
\text { al., 2020 } \\
\text { [22] }\end{array}$ & Italy (Tuscany) & $\begin{array}{l}\text { Case control } \\
\text { (phone/web } \\
\text { survey) }\end{array}$ & $\begin{array}{l}740 \text { non-demented PD } \\
\text { patients who had } \\
\text { performed at least } \\
\text { one outpatient visit } \\
\text { from January } 1 \text { to } \\
\text { December } 312019 \\
\text { living in Tuscany }\end{array}$ & 7 & $4(57.1 \%)$ & 75.7 & 9.3 & 4 & NR & $1(14.3 \%)$ & NR & NR & 0 & $\begin{array}{l}\text { PD without COVID-19 } \\
\text { matched for age and } \\
\text { PD duration; general } \\
\text { population with } \\
\text { COVID-19 compared } \\
\text { adjusting for age }\end{array}$ \\
\hline $\begin{array}{l}\text { Zhang et al., } \\
2020[23]\end{array}$ & Mostly US & $\begin{array}{l}\text { Case control } \\
\quad \text { (medical } \\
\text { records) }\end{array}$ & $\begin{array}{l}\text { All COVID-19 positive } \\
\text { patients via the } \\
\text { TriNetX COVID-19 } \\
\text { research network }\end{array}$ & 694 & $418(60.2 \%)$ & 79 & $\mathrm{NR}$ & $\mathrm{NR}$ & NR & $148(21.3 \%)$ & NR & NR & NR & $\begin{array}{l}\text { General population with } \\
\text { COVID-19 compared } \\
\text { adjusting for age }\end{array}$ \\
\hline $\begin{array}{l}\text { Zhai et al., } \\
\quad 2020 \text { [27] }\end{array}$ & China (Wuhan) & $\begin{array}{l}\text { Case control } \\
\text { (medical } \\
\text { records) }\end{array}$ & $\begin{array}{l}\text { Clinical data of } \\
\text { COVID-19 positive } \\
\text { patients in the West } \\
\text { Branch of Union } \\
\text { Hospital in Wuhan } \\
\text { between } 28 \text { January } \\
\text { and } 29 \text { February } 2020\end{array}$ & 10 & $3(30 \%)$ & 72.1 & 7.1 & 10 & 4 & $3(30 \%)$ & $\mathrm{NR}$ & NR & 0 & $\begin{array}{l}\text { General population with } \\
\text { COVID-19 matched } \\
\text { for age }\end{array}$ \\
\hline $\begin{array}{l}\text { Vignatelli et } \\
\text { al., 2020 } \\
\text { [28] }\end{array}$ & Italy (Bologna) & $\begin{array}{l}\text { Case control } \\
\text { (medical } \\
\text { records) }\end{array}$ & $\begin{array}{l}\text { All patients registered in } \\
\text { the ParkLink } \\
\text { database admitted for } \\
\text { COVID-19 }\end{array}$ & 4 & $3(75 \%)$ & 76.5 & NR & 4 & 2 & $1(25 \%)$ & $2(50 \%)$ & NR & $1 \mathrm{LCIG}$ & $\begin{array}{l}\text { General population with } \\
\text { COVID-19 compared } \\
\text { adjusting for age }\end{array}$ \\
\hline $\begin{array}{l}\text { Santos Garcia } \\
\quad \text { et al., } 2020 \\
\text { [20] }\end{array}$ & Spain & $\begin{array}{l}\text { Cross- } \\
\quad \text { sectional } \\
\text { (phone/web } \\
\text { survey) }\end{array}$ & $\begin{array}{l}568 \text { PD patients or } \\
\text { caregivers reached by } \\
\text { interview on } \\
\text { voluntary basis }\end{array}$ & 15 & $7(46.7 \%)$ & 65.6 & 6.8 & 5 (1 in ICU) & $\mathrm{NA}$ & $0(0 \%)$ & $\mathrm{NR}$ & NR & NR & No \\
\hline $\begin{array}{l}\text { Artusi et al., } \\
\quad 2020[21]\end{array}$ & Italy (Piedmont) & $\begin{array}{l}\text { Cross- } \\
\quad \text { sectional } \\
\text { (phone/web } \\
\text { survey) }\end{array}$ & $\begin{array}{l}\text { 1,407 random PD } \\
\text { patients living in } \\
\text { Piedmont }\end{array}$ & 8 & $5(62.5 \%)$ & 74 & 12.1 & 7 & 6 & $6(75 \%)$ & 3 & 1 & $1 \mathrm{LCIG}$ & NA \\
\hline $\begin{array}{l}\text { Brown et al., } \\
2020 \text { [25] }\end{array}$ & Mostly US & $\begin{array}{l}\text { Cross- } \\
\quad \text { sectional } \\
\text { (phone/web } \\
\text { survey) }\end{array}$ & $\begin{array}{l}\text { All people with and } \\
\text { without PD } \\
\text { participating in the } \\
\text { online study Fox } \\
\text { Insight who } \\
\text { responded to online } \\
\text { survey }\end{array}$ & 51 & $24(47 \%)$ & 65 & $\mathrm{NA}$ & 5 (2 in ICU) & NA & $0(0 \%)$ & $\mathrm{NR}$ & NR & NR & $\begin{array}{l}\text { General population with } \\
\text { COVID-19 compared } \\
\text { adjusting for age }\end{array}$ \\
\hline
\end{tabular}




\begin{tabular}{|c|c|c|c|c|c|c|c|c|c|c|c|c|c|c|}
\hline $\begin{array}{l}\text { Antonini et al., } \\
2020 \text { [12] }\end{array}$ & $\begin{array}{l}\text { Italy/UK } \\
\quad \text { (Padua-London) }\end{array}$ & $\begin{array}{l}\text { Case series } \\
\text { (in-hospital } \\
\text { assessment) }\end{array}$ & $\mathrm{NA}$ & $\begin{array}{l}2 \text { advanced PD } \\
\quad \text { from Italy }+8 \\
\text { advanced PD } \\
\text { from UK }\end{array}$ & $6(60 \%)$ & 78.3 & 12.7 & $\begin{array}{l}3 \text { required CPAP } \\
\text { or ICU }\end{array}$ & 10 & $4(40 \%)$ & 2 & 5 & $\begin{array}{l}3 \text { LCIG, } 1 \\
\text { STN-DBS + } \\
\text { apomorphine } \\
\text { pump }\end{array}$ & $\mathrm{NA}$ \\
\hline $\begin{array}{l}\text { Fasano et al., } \\
2020 \text { [17] }\end{array}$ & $\begin{array}{l}\text { Italy, Iran, Spain, } \\
\text { UK }\end{array}$ & $\begin{array}{l}\text { Case series } \\
\quad \text { (medical } \\
\text { records or } \\
\text { phone/web } \\
\text { survey) }\end{array}$ & $\mathrm{NA}$ & 117 & $74(63.2 \%)$ & 71.4 & 9.4 & 37 & 97 & $23(19.7 \%)$ & NR & $\mathrm{NR}$ & 4 LCIG, 6 DBS & NA \\
\hline $\begin{array}{l}\text { Hainque and } \\
\text { Ghrabli, } \\
2020 \text { [19] }\end{array}$ & France & $\begin{array}{l}\text { Case series } \\
\text { (in-hospital } \\
\text { assessment) }\end{array}$ & NA & 2 & $1(50 \%)$ & 78 & 22 & 2 & NR & $2(100 \%)$ & no & 1 & 2 STN-DBS & NA \\
\hline $\begin{array}{l}\text { De Marcaida } \\
\text { et al., } 2020 \\
\text { [24] }\end{array}$ & US (Connecticut) & $\begin{array}{l}\text { Case series } \\
\text { (in-hospital } \\
\text { assessment) }\end{array}$ & $\begin{array}{l}\text { All COVID-19 positive } \\
\text { patients with } \\
\text { movement disorders } \\
\text { from the Chase } \\
\text { Family Movement } \\
\text { Disorders Center } \\
\text { (CFMDC) and } \\
\text { PD-COVID+ } \\
\text { admitted to affiliate } \\
\text { hospitals in } \\
\text { Connecticut }\end{array}$ & 21 & $13(59.1 \%)$ & 75.2 & 9.9 & 16 & 18 & $6(28.6 \%)$ & 14 & NR & NR & NA \\
\hline $\begin{array}{l}\text { Lo Monaco et } \\
\text { al., 2020 } \\
\text { [26] }\end{array}$ & Italy (Rome) & $\begin{array}{l}\text { Case series } \\
\text { (in-hospital } \\
\text { assessment) }\end{array}$ & $\begin{array}{l}\text { Description of five } \\
\text { patients with } \\
\text { parkinsonism, who } \\
\text { tested COVID-19 } \\
\text { positive at the } \\
\text { Fondazione } \\
\text { Policlinico } \\
\text { Universitario } \\
\text { "Agostino Gemelli" }\end{array}$ & 2 & $1(50 \%)$ & 80.5 & NR & 2 & 2 & $1(50 \%)$ & 1 & 0 & 0 & NA \\
\hline $\begin{array}{l}\text { Filatov et al., } \\
2020 \text { [18] }\end{array}$ & China & $\begin{array}{l}\text { Case report } \\
\text { (in-hospital } \\
\text { assessment) }\end{array}$ & NA & 1 & $1(100 \%)$ & 74 & NR & 1 & 1 & $\begin{array}{l}0 \text { ("Critical } \\
\text { ill") }\end{array}$ & no & NR & NR & NA \\
\hline $\begin{array}{l}\text { Lo Monaco et } \\
\text { al., 2021 } \\
{[29]} \\
\end{array}$ & Italy (Rome) & $\begin{array}{l}\text { Case report } \\
\text { (in-hospital } \\
\text { assessment) }\end{array}$ & $\mathrm{NA}$ & 1 & $0(0 \%)$ & 58 & 8 & 0 & NR & 0 & no & 1 & 0 & NA \\
\hline
\end{tabular}

DBS, deep brain stimulation; ICU, intensive care unit; LCIG, Levodopa/Carbidopa intestinal gel infusion; NA, not applicable; NR, not reported; PD, Parkinson's disease; PD-COVID+, patients with Parkinson's disease with a diagnosis of COVID-19; STN, subthalamic nucleus. *In these studies, PD-COVID+ were defined as confirmed and probable cases, according to real-time PCR assay or symptoms compatible with COVID-19 and ascertained contact with a PCR-confirmed case. 
with COVID-19 and without PD: among 78,355 COVID-19 patients without PD, 4,290 (5.5\%) died compared to 148 out of the 694 PD-COVID+ (21.3\%) [23]. Moreover, the authors demonstrated that the mortality risk in people with PD is significantly higher than that of the general population (odds ratio 1.27), even when controlling for age, sex, and race differences.

\section{PD duration: risk and outcome of COVID-19 disease}

Two case series [12, 17], two cross-sectional [21, 25], and one case control [27] studies suggested that advanced PD may be a risk factor for a worse COVID19 outcome. In particular, ten PD patients from Padua (Italy) and London (UK) were reported having a high mortality rate $(40 \%)$; given their mean age of 78.3 years and disease duration of 12.7 years, the authors hypothesized that older age and longer PD duration might increase patients' susceptibility to more severe COVID-19 [12]. Similarly, a cross-sectional study reporting prevalence and outcome of COVID19 in PD patients living in Piedmont, Italy, found an extremely high mortality rate $(75 \%)$ among eight PD-COVID+ with a mean age of 74 years and a disease duration of 12.1 years; in this study, patients' mean age of death was 74.8 years, and the mean disease duration was 15 years [21]. Another case series of 117 PD-COVID+ from tertiary centers in different countries identified a significant effect of concomitant dementia and PD duration on the mortality rate [17], while a study based on an electronic survey reporting on 51 PD-COVID+ found that a longer PD duration is associated with a higher risk of pneumonia, the need for supplemental oxygen, or hospitalization [25]. Finally, one case control study reported that two out of three (66\%) non-survivors had more than ten years of PD course vs. one out of seven (14\%) survivors [27].

When considering the susceptibility for developing COVID-19, three case-control studies did not identify any significant difference in age and disease duration between PD patients with and without COVID-19 $[15,16,22]$. Specifically, two studies observed that PD patients who developed symptomatic COVID-19 were neither older nor had a longer disease duration than those screened negative [15,22], while the other one found a similar disease duration and an identical Hoehn and Yahr (HY) stage between PD-COVID+ and PD patients without COVID-19 [16].

\section{Risk factors for COVID-19 in PD: Comparison} with control groups

Six studies reported comparisons between PDCOVID+ and PD patients who did not develop COVID-19 (PD-COVID-) [15, 16, 20, 22, 23, 25].

The study from Italian patients living in Lombardy compared 12 PD-COVID+ against 36 PD-COVID, matched for sex, age, and disease duration. No between-group differences were found for body mass index, smoking habit, seasonal vaccination in 2019, PD phenotype, HY stage, diagnosis of dementia, and therapies, nor for comorbidities [15]. A study on Spanish patients reported that motor fluctuations, dementia, and behavioral disorders were present twice as much in PD-COVID- $(n=553)$ compared to PD-COVID+ $(n=15)$, with a trend towards a significant difference [20]. Moreover, cardiovascular risk factors and cardiovascular diseases were more frequently observed in PD-COVID+, with dyslipidemia being significantly more prevalent in this group [20].

Another study on Italian patients living in Lombardy, Italy, reported that PD-COVID+ $(n=105)$ were younger, more frequently obese, and with a higher prevalence of chronic obstructive pulmonary disease than PD-COVID- $(n=1,381)$ [16]. Moreover, PD-COVID+ needed hospitalization less frequently when compared to family members with COVID-19 but without $\mathrm{PD}$, while the mortality rate was similar between groups $(5.7 \%$ vs. $7.6 \%)$.

The study on Italian PD patients living in Tuscany reported a higher prevalence of diabetes and hypertension in 7 PD-COVID+ when compared to 14 PD-COVID- matched for age and disease duration, in the absence of other differences in comorbidities or antiparkinsonian therapies [22].

One study based on an electronic survey (with $80 \%$ of respondents living in the US) found that PDCOVID+ $(n=51)$ were more likely to be smokers and have a previous history of heart disease than PD-COVID- $(n=5,378)$. Conversely, PD-COVID+ compared to people not suffering from PD who developed COVID-19 $(n=26)$, were more likely to be older, male, and less likely to have lung disease [25].

\section{Protective factors for COVID-19 in PD}

Two studies highlighted some associations between the prevalence of COVID-19 and patient clinical features. In particular, one study on PD patients living in Lombardy, Italy, observed that a significantly higher percentage of PD patients 
who did not develop SARS-CoV-2 infection were supplemented with vitamin $\mathrm{D}$ in comparison with those who developed the infection $(22.9 \%$ vs. $12.4 \%$ ) [16]. Another study on 568 Spanish PD patients who underwent an electronic interview reported that none of the $82 \mathrm{PD}$ patients receiving amantadine was infected by COVID-19, with the difference showing a trend towards significance in comparison to patients who were not on amantadine treatment [20]. From nine studies reporting complete information on patients' medications [12, 15-17, 20, $21,24,26,27]$, it appears that $2.7 \%$ of PD-COVID+ $(n=8 / 299)$ were on amantadine treatment.

\section{DISCUSSION}

In this review, we evaluated all published articles reporting data on PD patients with a confirmed diagnosis of COVID-19. The median prevalence of infection ranged from $0.6 \%$ to $8.5 \%$, depending on the country and regions where the patients lived. In most studies, SARS-CoV-2 infection prevalence in the PD population was below $1 \%$, except for studies on patients living in Lombardy $[15,16]$, the first and the most affected Italian region, which showed the highest prevalence. From a total of 1,061 PDCOVID+, we found a hospitalization rate of $28.6 \%$ and a mortality rate of $18.9 \%$. Noteworthy, from six studies reporting such information, $46.8 \%$ of PDCOVID+ patients were living in a nursing home.

On July 1, 2020, the prevalence of COVID-19 in the general population of Italy, Spain, and the US (the countries most represented in the included studies) was $0.4,0.5$, and $0.8 \%$, respectively [1]. Thus, in most studies, the prevalence of SARS-CoV-2 infection in PD patients was not consistently higher than that of each country's general population. On the contrary, a much higher COVID-19 prevalence in PD was observed in the two studies reporting data from people living in Lombardy, Italy. Indeed, the prevalence of COVID-19 in Lombardy on July 1, 2020, was $0.9 \%$, which is significantly lower than the 7.1 and $8.5 \%$ found in PD patients from the same geographical area $[15,16]$. The higher prevalence reported in Lombardy could be partially explained by the fact that the two studies also included patients without a molecular test confirmation, leading to a possible overestimation of the real COVID-19 prevalence in the PD population. Moreover, the hypothesis that people with PD could be at higher risk for developing COVID-19 should take into account that PD patients are generally older than the general population, with age being a known risk factor for COVID-19 [5, $6]$. On the other hand, the prevalence of infection could also be biased by a more cautious behavior of PD patients since they have been considered as a higher-risk population $[15,20,30]$. Thus, current literature does not help to clarify whether PD should be considered a risk factor for developing symptomatic COVID-19 infection.

We found more consistent evidence on the clinical impact of COVID-19 in people with PD. Indeed, collected data point out the higher frailty of PD patients [30]. On July 1, 2020, the case fatality rates due to COVID-19 in Italy, Spain, and the US were 14.4, 11.5 , and $4.9 \%$, respectively [1], which are much lower than the percentage we derived from the 16 studies included in the current review. Likewise, a large sample study on case fatality of PD-COVID+ demonstrated that the risk of death for COVID-19 in people with PD is about $30 \%$ higher than in the general population, after adjusting the statistical analysis for age, sex, and race differences [23]. While the case fatality seems to be higher in PD patients compared with the general population of similar age (estimated about $4.5 \%$ in people $\geq 60$ years [31]), it is possible that the frailty related to a chronic neurological condition, the limited mobility, and the presence of cognitive impairment play the major role in the increased mortality rate. Indeed, a chronic neurological disorder was found as an independent predictor of death; dementia, in particular, was associated with a worse COVID-19 outcome [32, 33].

Summarizing data from all studies, we found a slightly higher prevalence of males $(58.4 \%)$, probably reflecting the higher number of males affected by PD [34], a median age of infected patients of 74 years (range 58-80.5), and a median disease duration of 9.4 years (range 6.3-22). These findings indicate a higher susceptibility to COVID-19 for PD patients with older age and longer disease duration. This is suggested by some studies [12, 16, 21, 27], although some case-control studies did not confirm such a hypothesis $[15,16]$. Studies that included control groups found no consistent correlations between specific clinical features and the risk of being infected by SARS-CoV-2. In fact, one study including a sex, age-, and disease duration-matched control group did not report any significant difference in body mass index, smoking, seasonal vaccination in 2019, PD phenotype and stage, therapies, and comorbidities [15]. Conversely, a study on Spanish PD patients reported a trend toward a higher severity of motor 
fluctuations and neuropsychological impairments in those patients who did not develop COVID-19 [20]. The same authors of this study suggest that this finding could be related to stricter prevention measures applied to advanced and cognitively impaired patients. Moreover, the low number of PD-COVID+ retrieved in the study $(n=15)$ should be highlighted as a potential bias for this finding. Remarkably, one study found that PD-COVID+ were significantly younger and more frequently obese than PD-COVID[16]. Cardiovascular risk factors and a higher prevalence of chronic obstructive pulmonary disease were found as predisposing factors for developing COVID19 among PD patients, as for the general population $[6,16,20,25,35]$.

Some potential protective factors have been proposed. The study on 568 PD patients living in Spain found that none of the 82 patients receiving amantadine resulted being infected by SARS-CoV-2 [20]. Another study on 15 patients with neurological diseases (PD or multiple sclerosis) who were on amantadine therapy reported no signs or symptoms of infection despite a confirmed diagnosis of COVID-19 [36]. Our review highlighted that among a total number of 299 PD patients with COVID-19 for whom therapy information was available, only eight $(2.7 \%)$ were on amantadine therapy. The potential of amantadine as a protective drug is further supported by a drug screen gene expression study suggesting that amantadine could decrease the replication and infectivity of the SARS-CoV-2 [37]. Taken together, these data suggest amantadine as a possible promising drug to protect from COVID-19 viral replication in vivo.

The second potential protective factor suggested by published studies and supported by its biological characteristics is vitamin D. It has been hypothesized that vitamin D could reduce the risk of infection through several mechanisms, such as reducing the concentration of pro-inflammatory cytokines [38]. Moreover, two studies investigating the effect of vitamin D levels in the general population found an inverse association between its serum concentration and both prevalence and mortality of COVID-19 $[39,40]$, although this evidence requires confirmation from randomized controlled clinical trials and cohort studies on larger populations [41]. Even in the limited number of published data on COVID19 in PD, a correlation between higher vitamin D intake and lower risk of COVID-19 was found [16]. However, it is important to take into account that none of the published studies so far on COVID-19 in PD populations are adequate to prove the efficacy of amantadine and vitamin D. Specifically-designed studies with adequate sample size and control group should be performed to assess a possible protective role of these drugs from COVID-19. Indeed, one of the main limitations of the present review is the inclusion of studies with considerable heterogeneity in the study design, including case reports and case series, which reduce the strength of the findings. Moreover, the lack of studies from low-income countries may also limit the generalization of our results, especially regarding data on hospitalization, therapies, and possibly infection outcome.

\section{CONCLUSION}

Available literature points out a possible worse clinical outcome in people with PD who develop COVID-19. On the contrary, data published so far do not provide sufficient evidence for considering PD as a condition at higher risk for COVID-19 infection. Pending further studies, a longer PD duration could be regarded as a potential risk factor for higher susceptibility and worse outcome in PD patients with COVID-19, as well as older age and cardiovascular or pulmonary comorbidities. Finally, the role of vitamin $\mathrm{D}$ and amantadine in making PD patients less prone to develop COVID-19 infection or severe symptoms is particularly intriguing but needs confirmation by tailored clinical trials to clarify their protective action.

Given the incessant status of alert related to the persistence of the pandemic and the knowledge gaps on various aspects of the impact of COVID-19 in people with $\mathrm{PD}$, a continuous monitoring of $\mathrm{PD}$ patients and set-up larger databases for prospective and retrospective data collection in big cohorts of patients and age-matched control groups of people without neurological comorbidities are necessary (as per the ParkLink Bologna or the Fox Insight database).

\section{ACKNOWLEDGMENTS}

This study did not receive specific funding.

\section{CONFLICT OF INTEREST}

The authors have no conflict of interest to report.

\section{REFERENCES}

[1] World Health Organization. Coronavirus disease (COVID19) dashboard (2020) http://covid19.who.int, Accessed on October 24, 2020. 
[2] Jiang F, Deng L, Zhang L, Cai Y, Cheung CW, Xia Z (2020) Review of the clinical characteristics of Coronavirus disease 2019 (COVID-19). J Gen Intern Med 35, 1545-1549.

[3] Ellul MA, Benjamin L, Singh B, Lant S, Michael BD, Easton A, Kneen R, Defres S, Sevjar J, Solomon T (2020) Neurological associations of COVID-19. Lancet Neurol 19, 767-783.

[4] Sulzer D, Antonini A, Leta V, Nordvig A, Smeyne RJ, Goldman JE, Al-Dalahmah O, Zecca L, Sette A, Bubacco L, Meucci O, Moro E, Harms AS, Xu Y, Fahn S, Ray Chaudhuri K (2020) COVID-19 and possible links with Parkinson's disease and parkinsonism: From bench to bedside. NPJ Parkinsons Dis 6, 18.

[5] Wang D, Hu B, Hu C, Zhu F, Liu X, Zhang J, Wang B, Xiang H, Cheng Z, Xiong Y, Zhao Y, Li Y, Wang X, Peng Z (2020) Clinical characteristics of 138 hospitalized patients with 2019 novel Coronavirus-infected pneumonia in Wuhan, China. JAMA 323, 1061-1069.

[6] Guan WJ, Liang WH, Zhao Y, Liang HR, Chen ZS, Li YM, Liu XQ, Chen RC, Tang CL, Wang T, Ou CQ, Li L, Chen PY, Sang L, Wang W, Li JF, Li CC, Ou LM, Cheng B, Xiong S, Ni ZY, Xiang J, Hu Y, Liu L, Shan H, Lei CL, Peng YX, Wei L, Liu Y, Hu YH, Peng P, Wang JM, Liu JY, Chen Z, Li G, Zheng ZJ, Qiu SQ, Luo J, Ye CJ, Zhu SY, Cheng LL, Ye F, Li SY, Zheng JP, Zhang NF, Zhong NS, He JX (2020) Comorbidity and its impact on 1590 patients with COVID-19 in China: A nationwide analysis. Eur Respir J 55, 2000547.

[7] Romagnolo A, Balestrino R, Imbalzano G, Ciccone G, Riccardini F, Artusi CA, Bozzali M, Ferrero B, Montalenti E, Montanaro E, Rizzone MG, Vaula G, Zibetti M, Lopiano L (2020) Neurological comorbidity and severity of COVID19. J Neurol, doi: 10.1007/s00415-020-10123-y.

[8] García-Azorín D, Martínez-Pías E, Trigo J, HernándezPérez I, Valle-Peñacoba G, Talavera B, Simón-Campo P, de Lera M, Chavarría-Miranda A, López-Sanz C, GutiérrezSánchez M, Martínez-Velasco E, Pedraza M, Sierra Á, Gómez-Vicente B, Guerrero Á, Ezpeleta D, Peñarrubia MJ, Gómez-Herreras JI, Bustamante-Munguira E, Abad-Molina C, Orduña-Domingo A, Ruiz-Martin G, Jiménez-Cuenca MI, Juarros S, Del Pozo-Vegas C, Dueñas-Gutierrez C, de Paula JMP, Cantón-Álvarez B, Vicente JM, Arenillas JF (2020) Neurological comorbidity is a predictor of death in Covid-19 disease: A cohort study on 576 patients. Front Neurol 11, 781.

[9] Li YC, Bai WZ, Hashikawa T (2020) The neuroinvasive potential of SARS-CoV2 may play a role in the respiratory failure of COVID-19 patients. J Med Virol 92, 552-555.

[10] Baig AM, Khaleeq A, Ali U, Syeda H (2020) Evidence of the COVID-19 virus targeting the CNS: Tissue distribution, host-virus interaction, and proposed neurotropic mechanisms. ACS Chem Neurosci 11, 995-998.

[11] Lechien JR, Chiesa-Estomba CM, De Siati DR, Horoi $\mathrm{M}$, Le Bon SD, Rodriguez A, Dequanter D, Blecic S, El Afia F, Distinguin L, Chekkoury-Idrissi Y, Hans S, Delgado IL, Calvo-Henriquez C, Lavigne P, Falanga C, Barillari MR, Cammaroto G, Khalife M, Leich P, Souchay C, Rossi C, Journe F, Hsieh J, Edjlali M, Carlier R, Ris L, Lovato A, De Filippis C, Coppee F, Fakhry N, Ayad T, Saussez S (2020) Olfactory and gustatory dysfunctions as a clinical presentation of mild-to-moderate forms of the coronavirus disease (COVID-19): A multicenter European study. Eur Arch Otorhinolaryngol 277, 2251-2261.
[12] Antonini A, Leta V, Teo J, Chaudhuri KR (2020) Outcome of Parkinson's disease patients affected by COVID-19. Mov Disord 35, 905-908.

[13] Fazzini E, Fleming J, Fahn S (1992) Cerebrospinal fluid antibodies to coronavirus in patients with Parkinson's disease. Mov Disord 7, 153-158.

[14] Moher D, Liberati A, Tetzlaff J, Altman DG; PRISMA Group (2009) Preferred reporting items for systematic reviews and meta-analyses: The PRISMA statement. PLoS Med 6, e1000097.

[15] Cilia R, Bonvegna S, Straccia G, Andreasi NG, Elia AE, Romito LM, Devigili G, Cereda E, Eleopra R (2020) Effects of COVID-19 on Parkinson's disease clinical features: A community-based case-control study. Mov Disord 35, 12871292.

[16] Fasano A, Cereda E, Barichella M, Cassani E, Ferri V, Zecchinelli AL, Pezzoli G (2020) COVID-19 in Parkinson's disease patients living in Lombardy, Italy. Mov Disord 35, 1089-1093.

[17] Fasano A, Elia AE, Dallocchio C, Canesi M, Alimonti D, Sorbera C, Alonso-Canovas A, Pezzoli G (2020) Predictors of COVID-19 outcome in Parkinson's disease. Parkinsonism Relat Disord 78, 134-137.

[18] Filatov A, Sharma P, Hindi F, Espinosa PS (2020) Neurological complications of Coronavirus disease (COVID-19): Encephalopathy. Cureus 12, e7352.

[19] Hainque E, Grabli D (2020) Rapid worsening in Parkinson's disease may hide COVID-19 infection. Parkinsonism Relat Disord 75, 126-127.

[20] Santos-García D, Oreiro M, Pérez P, Fanjul G, Paz González JM, Feal Painceiras MJ, Cores Bartolomé C, Valdés Aymerich L, García Sancho C, Castellanos Rodrigo MDM (2020) Impact of COVID-19 pandemic on Parkinson's disease: A cross-sectional survey of 568 spanish patients. Mov Disord 35(10), 1712-1716.

[21] Artusi CA, Romagnolo A, Imbalzano G, Marchet A, Zibetti M, Rizzone MG, Lopiano L (2020) COVID-19 in Parkinson's disease: Report on prevalence and outcome. Parkinsonism Related Disord 80, 7-9.

[22] Del Prete E, Francesconi A, Palermo G, Mazzucchi S, Frosini D, Morganti R, Coleschi P, Raglione LM, Vanni P, Ramat S, Novelli A, Napolitano A, Battisti C, Giuntini M, Rossi C, Menichetti C, Ulivelli M, De Franco V, Rossi S, Bonuccelli U, Ceravolo R (2020) Prevalence and impact of COVID-19 in Parkinson's disease: Evidence from a multi-center survey in Tuscany region. $J$ Neurol, doi: 10.1007/s00415-020-10002-6

[23] Zhang Q, Shultz JL, Aldridge GM, Simmering JE, Narayanan NS (2020) Coronavirus disease 2019 case fatality and Parkinson's disease. Mov Disord 35, 1914-1915.

[24] De Marcaida JA, Lahrmann J, Machado D, Bluth L, Dagostine M, Moro-de Casillas M, Bortan E, Kanchana S, Alberts M (2020) Clinical characteristics of Coronavirus disease 2019 (COVID-19) among patients at a movement disorder center. Geriatrics 5, 54.

[25] Brown EG, Chahine LM, Goldman SM, Korell M, Mann E, Kinel DR, Arnedo V, Marek KL, Tanner CM (2020) The effect of the COVID-19 pandemic on people with Parkinson's disease. J Parkinsons Dis 10, 1365-1377.

[26] Lo Monaco MR, Colacicco G, Marotta J, Bentivoglio AR, GEMELLI AGAINST COVID-19 group (2020) An educational case series of Parkinson's disease during COVID-19 pandemic. Rev Neurol (Paris), doi: 10.1016/j.neurol.2020.07.007 
[27] Zhai H, Lv Y, Xu Y, Wu Y, Zeng W, Wang T, Cao X, Xu Y (2021) Characteristic of Parkinson's disease with severe COVID-19: A study of 10 cases from Wuhan. J Neural Transm (Vienna) 3, 1-12.

[28] Vignatelli L, Zenesini C, Belotti LMB, Baldin E, Bonavina G, Calandra-Buonaura G, Cortelli P, Descovich C, Fabbri G, Giannini G, Guarino M, Pantieri R, Samoggia G, Scaglione C, Trombetti S, D'Alessandro R, Nonino F; ParkLink Bologna group (2020) Risk of hospitalization and death for COVID-19 in people with Parkinson's disease or parkinsonism. Mov Disord, doi: 10.1002/mds.28408

[29] Lo Monaco MR, Bentivoglio AR, Fusco D, Calabresi P, Piano C (2021) Subacute onset dystonia in a woman affected by Parkinson's disease following SARS-COV-2 infection. Clin Park Relat Disord 4, 100082.

[30] Tenison E, Henderson EJ (2020) Multimorbidity and frailty: Tackling complexity in Parkinson's disease. J Parkinsons Dis 10, S85-S91.

[31] Verity R, Okell LC, Dorigatti I, Winskill P, Whittaker C, Imai N, Cuomo-Dannenburg G, Thompson H, Walker PGT, Fu H, Dighe A, Griffin JT, Baguelin M, Bhatia S, Boonyasiri A, Cori A, Cucunubá Z, FitzJohn R, Gaythorpe K, Green W, Hamlet A, Hinsley W, Laydon D, Nedjati-Gilani G, Riley S, van Elsland S, Volz E, Wang H, Wang Y, Xi X, Donnelly CA, Ghani AC, Ferguson NM (2020) Estimates of the severity of coronavirus disease 2019: A model-based analysis. Lancet Infect Dis 20, 669-677.

[32] García-Azorín D, Martínez-Pías E, Trigo J, HernándezPérez I, Valle-Peñacoba G, Talavera B, Simón-Campo P, de Lera M, Chavarría-Miranda A, López-Sanz C, GutiérrezSánchez M, Martínez-Velasco E, Pedraza M, Sierra Á, Gómez-Vicente B, Guerrero Á, Ezpeleta D, Peñarrubia MJ, Gómez-Herreras JI, Bustamante-Munguira E, Abad-Molina C, Orduña-Domingo A, Ruiz-Martin G, Jiménez-Cuenca MI, Juarros S, Del Pozo-Vegas C, Dueñas-Gutierrez C, de Paula JMP, Cantón-Álvarez B, Vicente JM, Arenillas JF (2020) Neurological comorbidity is a predictor of death in Covid-19 disease: A cohort study on 576 patients. Front Neurol 11, 781.
[33] Ghaffari M, Ansari H, Beladimoghadam N, Aghamiri SH, Haghighi M, Nabavi M, Mansouri B, Mehrpour M, Assarzadegan F, Hesami O, Sedaghat M, Farahbakhsh M, Lima BS (2021) Neurological features and outcome in COVID-19: Dementia can predict severe disease. $J$ Neurovirol doi: 10.1007/s13365-020-00918-0

[34] Tysnes OB, Storstein A (2017) Epidemiology of Parkinson's disease. J Neural Transm (Vienna) 124, 901-905.

[35] Du RH, Liang LR, Yang CQ, Wang W, Cao TZ, Li M, Guo GY, Du J, Zheng CL, Zhu Q, Hu M, Li XY, Peng P, Shi HZ (2020) Predictors of mortality for patients with COVID-19 pneumonia caused by SARS-CoV-2: A prospective cohort study. Eur Respir J 55, 2000524.

[36] Rejdak K, Grieb P (2020) Adamantanes might be protective from COVID-19 in patients with neurological diseases: Multiple sclerosis, parkinsonism and cognitive impairment. Mult Scler Relat Disord 42, 102163.

[37] Smieszek SP, Przychodzen BP, Polymeropoulos MH (2020) Amantadine disrupts lysosomal gene expression: A hypothesis for COVID19 treatment. Int J Antimicrob Agents 55, 106004.

[38] Mitchell F (2020) Vitamin-D and COVID-19: Do deficient risk a poorer outcome? Lancet Diabetes Endocrinol 8, 570.

[39] Ilie PC, Stefanescu S, Smith L (2020) The role of vitamin D in the prevention of coronavirus disease 2019 infection and mortality. Aging Clin Exp Res 32, 1195-1198.

[40] D'Avolio A, Avataneo V, Manca A, Cusato J, De Nicolò A, Lucchini R, Keller F, Cantù M (2020) 25-Hydroxyvitamin D concentrations are lower in patients with positive PCR for SARS-CoV-2. Nutrients 12, 1359.

[41] Ali N (2020) Role of vitamin D in preventing of COVID-19 infection, progression and severity. J Infect Public Health 13, 1373-1380. 